\title{
Corporate Governance and Dividend Policy : An Empirical Analysis From Borsa Istanbul Corporate Governance Index (XKURY)
}

\author{
Alev Dilek Aydin ${ }^{1} \&$ Seyma Caliskan Cavdar ${ }^{1}$ \\ ${ }^{1}$ Faculty of Business, Department of International Trade and Business, Halic University, Istanbul, Turkey \\ Correspondence: Alev Dilek Aydin, Faculty of Business, Department of International Trade and Business, Halic \\ University, Istanbul, Turkey. E-mail : alevdil@yahoo.com \\ Received: July 14, 2015 \\ Accepted: July 31, 2015 \\ Online Published: August 2, 2015 \\ doi:10.5430/afr.v4n3p66 \\ URL: http://dx.doi.org/10.5430/afr.v4n3p66
}

\begin{abstract}
The aim of this research is to analyze the potential relationship between corporate governance and dividend policy. To conduct this research, a sample of 19 corporations from the Borsa Istanbul (BIST) Corporate Governance Index (XKURY), which is composed of listed companies who accomplished a certain level of Corporate Governance Principles over the period of 2007-2014, were selected. OLS (Ordinary Least Squares) panel regression analysis has been performed. The potential relationship between ownership structure and dividend policy has also been analyzed by utilizing the independent variables of ownership concentration, managerial ownership and total foreign ownership. In addition to our independent variables, we also included return on equity (ROE) and firm size to our research in order to increase the explanatory power of our model. This study finds an insignificant relationship between corporate governance and dividend policy. On the other hand, we obtained significant positive relationship between total foreign ownership and dividend policy and significant negative relationships between ownership concentration and dividend policy and managerial ownership and dividend policy. Finally, we obtained significant negative association between return on equity (ROE) and dividend policy and significant positive association between firm size and dividend policy.
\end{abstract}

Keywords : Corporate governance, Dividend policy, Ownership structure, Borsa Istanbul Corporate Governance Index, Dividend payout ratio, Panel OLS regression

\section{Introduction}

Since the beginning of 2000s, various corporate scandals such as Enron, Xerox, Worldcom and Parmalat led to the questioning of credibility of even the largest companies and shaked the investor confidence. Accordingly, corporate governance has become a crucial subject that is widely discussed by different parties. In 2002, Sarbanes-Oxley Act was legalized with the aim of enhancing corporate governance mechanism in order to reassure public confidence and reliability of financial information (Wu et al., 2009).

It is widely accepted that bad management practices can cause the outbreak of the financial crises and company scandals in recent years. This circumtance has unearthed the importance of the concept of corporate governance practices. Corporate governance has various benefits for the firms, investors and the society in general. As Coskun and Sayilir (2012) point out, these benefits include improving firm performance, lowering the cost of capital, protecting shareholders' rights by ensuring conformance to legal requirements, strengthening corporate reputation, mitigating risk and increasing shareholder value. Additionally, the major benefits for the society include fighting corruption, providing the suitable environment for suitable investment and sustainable growth, thereby promoting competition and efficiency and developing capital markets. Empirical evidence asserts that companies in emerging countries are disadvantaged as compared to their counterparts because of weak corporate governance. However, as corporate governance practices are improved and appropriate division of power among shareholders, the board of directors and management is established, investor confidence and firms' access to capital will increase.

According to Shleifer and Vishny (1997), the main aim of corporate governance is to ensure that investors supplying finance to corporations recieve a fair return on their investments. Suppliers of equity can receive a return on their investments either through dividends or capital gains. As Mitton (2004) points out, agency theory states that outside shareholders may prefer dividends over retained earnings when they fear a possible expropriation by insiders and this preference for dividends may be even greater in emerging markets with weak shareholder protection. 
At the end of each fiscal year, successful firms produce profits that can either be kept in the firm or distributed to shareholders as dividends. Dividend is a very important shareholder right, sometimes affecting the decision of potential investors to invest in a company. For any given company, the optimal dividend payout ratio is affected by several factors such as invester preference for capital gains versus dividends, the firm's investment opportunities with positive Net Present Values (NPVs), the firm's target capital structure, and the availability and the cost of external financing opportunities. Chae, Kim and Lee (2009) argue that companies with better corporate governance pay larger dividends only if they are not subject to external financing constraints. This is due to the reason that larger dividend payouts will probably increase the likelihood for firms to raise external capital in the future and therefore firms that are having difficulty in raising external capital will not pay out larger dividends.

Dividend policy has always been one of the most controversial and frequently researched areas in the field of finance and dividend payout decision is an important part of corporate policy. The question of why firms pay dividends regularly becomes one of the main topics of financial studies for researchers. Shareholders generally believe that dividends provide important signals about the firm's ability to generate sufficient profits. The relationship between corporate governance and dividend policy in the emerging markets is an important research topic as part of the newly developing literature in corporate finance. Before the 1980s, major researchers concentrated on the relationship between these two subjects within the context of developed nations. However, as emerging markets began to receive a higher proportion from the global equity investments, investors have also started to pay more attention to the dividend policy choices of emerging markets. Researchers have soon recognized that the markets of some developing countries offer opportunities for further research as the financial markets of emerging countries have played significant roles in global financial activity.

Good corporate governance is the cornerstone of the development of strong and competitive corporate sector particularly in emerging countries. Many studies have investigated the relationship between corporate governance and dividend policy and majority of these researches conclude that companies which distribute higher cash dividends and follw stable dividend payout policies tend to minimize agency problems and the conflicts between majority and minority shareholders. As Jensen (1986) and Rozeff (1982) point out, if firms do not pay dividends to shareholders, managers will likely to use these resources under their control for their private benefits. Empirical evidence suggests that corporate governance has significant effect on dividend policy because it eliminates agency costs. Jensen (1986) asserts that by paying dividends to shareholders, the resources under the management's control will reduce.

The main aim of this study is to analyze the relationship between corporate governance and dividend policy. The present study contributes to existing literature by examining the effect of corporate governance on dividend policies of non-financial firms listed in the Borsa Istanbul (BIST) Corporate Governance Index (XKUR). It is a new index started to be calculated in 2007. Over the last few years, Turkish economy has been profoundly evaluating its corporate governance system, transparency and regularity framework. On this basis, a study of corporate governance on Turkish companies is crucial because of Turkey's economic growth and status among emerging market economies. The subject of the relationship between corporate governance and dividend policy has been studied extensively by many researchers in developed countries. However, it has not been studied adequately in most developing countries including Turkey. In this regard, this paper will be one of the studies to fill the gap in the existing literature.

To conduct our research, we selected 19 corporations from the Borsa Istanbul (BIST) Corporate Governance Index (XKURY), which is composed of listed companies which accomplished a certain level of Corporate Governance Principles over the period of 2007-2014. The ratings of companies included in the XKURY can be provided from the related disclosures of the companies sent to the Public Disclosure Platform (http://www.kap.gov.tr) or from website of Corporate Governance Association of Turkey (http:www.tkyd.org). The relationship between dividend policy and the ownership structure was also analyzed by utilizing the independent variables of ownership concentration, managerial ownership and total foreign ownership. We employed dividend payout ratio as the dependent variable of this study. The related data were obtained from the annual reports and websites of the selected corporations. This study concluded that there is a significant positive relationship between total foreign ownership and dividend policy for our selected companies. However, significant negative relationships were obtained between ownership concentration and dividend payment and managerial ownership and dividend payment. On the other hand, no significant relationship has been found to determine the relationship between corporate governance and dividend policy. We also obtained significant negative association between return on equity (ROE) and dividend policy and significant positive association between firm size and dividend policy. 
The structure of our study is as follows. The second section presents major literaure on the subject including the emerging market countries. The third section gives brief information about the methodology and the variables. The fourth section reviews empirical results. Finally, section 5 concludes the paper with suggestions for further research.

\section{Literature Review}

The relationship between the two concepts has been studied extensively by many researchers, but these empirical studies presented mixed results. Although several previous studies find a positive relationship between corporate governance and dividend policy and that good governance is related with larger dividend payouts (Michaely and Roberts, 2006 ; La Porta, Lopez-De Salinas, Shliefer, and Vishny, 2000 ; Sawicki 2005) several other studes indicate the opposite (Jo and Pan, 2009 ; Nielsen, 2006 ; Jiraporn and Ning 2006).

Since 1950s, many theoretical and empirical studies have been conducted leading to several theories that try to explain why and when firms pay dividends such as information content and signaling theory, agency theory and free cash flow (FCF) hypothesis and life cycle theory. The signaling theory dates back to the work of Lintner (1956), who indicates how market prices often react to changes in dividend rates. Although Modiglianni \&Miller (1961) posited that the dividend policy selected by a firm has no effect on firm value, a dividend policy change due to market perception may affect firm share price. The basic idea behind the signaling theory is that if insiders have better information about the future cash flows and the profitability of the firm, then dividends might convey valuable information not previously known by the investors. The core of the signaling theory is that changes in dividend rates communicate information beyond what is provided by the earning reports, financial announcements or all other types of accounting data to the investors. In other words, while initiations of dividends are perceived positively, reductions or omissions are perceived negatively among investors. (Bhattacharya, 1979 ; Miller and Rock, 1985 ; John and Williams, 1985)

The FCF hypothesis is closely associated with agency costs as Jensen (1986) states. He also argues that divergence of interests between managers and shareholders and self-interest motive of management were key factors leading to agency costs. Brush et al. (2000) contend that weak corporate governance is the main reason of the inefficiency in the allocation of FCF since the Board of Directors (BOD) generally implements policies to serve the management's interests at the expense of shareholders' wealth. The FCF hypothesis of Jensen (1986) states that in certain times when a firm obtains excessive surplus of FCF and has no profitable investment opportunities, management may have propensity to use excess cash in hand to the benefit of their personal interests at the expense of shareholders. Consequently, this situation leads to an increase in agency costs, inefficiency in resource allocation and unfair investment policies. Brush et al. (2000) support this argument and contend that sales growth contributes most to companies, which need cash flows but not to companies with adequate level of FCF. Chung et al. (2005) also argue that excessive FCF might have a negative impact on company profitability and stock valuation.

Several empirical studies indicate that corporate governance can mitigate fundamental agency problems that can occur between outside investors, controlling shareholders and managers by reducing the amount of free cash flows under the control of managers and thus reduces the probability of wasteful investment. Therefore, a firm's payout policy can solve potential agency problem, and lower the agency cost and minimize suboptimal managerial behavior (Easterbrook, 1984; Fama \& Jensen, 1983). Furthermore, distribution of cash also forces managers to look for external financing through capital market and as a result, managers will become subject to the screening of outside interest groups more frequently.

Berle and Means (1932) were the first to recognize the agency problem, who argued that agency costs might occur because of separation of ownership and control. Jensen and Meckling (1976) developed this argument and suggested that divergence of interests between agent (management) and principal (stockholders) might cause the agency problem. According to the agency theory of Jensen (1986), agency costs resulting from the divergence of ownership and control determine dividend policy. Due to these agency costs, managers may not always implement a dividend policy that maximizes shareholder benefits but rather they may choose a dividend policy that maximizes their own personal benefits (Jiraporn et al., 2011). Shleifer and Vishny (2000) assert that agency costs are lower in companies with high managerial ownership due to the better alignment of interests between managers and shareholders and in companies with more concentrated ownership that are better able to control managerial activities.

Dividend payment can also reduce opportunities of controlling shareholders for expropriation of minority shareholders. This view, in fact, depends on the combination of governance structures and laws protecting the rights of minority shareholders, which in turn affects dividend policy. In common-law countries, where there are stronger investor protection laws than civil-law countries, minority shareholders can use their legal powers to force companies to distribute cash dividends. If shareholder protection is poor, we observe distribution of earnings in very 
low rates. Companies prefer to pay out cash dividends to investors in countries with strong legal protection for shareholders, because the incentives to steal or misinvestment by managers are limited by law and because minority shareholders have enough legal power to extract it (Kaen, 2003).

Both firm-level corporate governance and country-level investor protection have great explanatory power for dividend payout policies. Mitton (2004) argues that there is a strong relationship between firm-level corporate governance and dividend payouts particularly in countries that offer strong shareholder protection. He also adds that firm-level corporate governance and country-level investor protection complements each other. In this context, the legal regime of the country is important in terms of offering a high level of protection to the investors and it increases the effectiveness of the firm-level corporate governance. However, as Kowalevski et al. (2007) point out, while country-level investor protection is important in preventing expropriation, firm-level corporate governance should also be given greater importance since corporate governance practices may differ widely even among firms in the same country subject to the same legal regime.

Empirical evidence indicates that there is a significant relationship between dividend payouts and the strength of shareholder rights. La Porta, Lopez-de-Silanes, Shleifer and Vishny (2000) present two possible hypotheses of dividends to determine the direction of the relationship between corporate governance quality and the dividend payout. The first hypothesis, the outcome hypothesis, is primarily based on the free cash flow hypothesis of Jensen (1986). It argues that opportunistic managers, managers of companies with weak corporate governance, prefer to retain cash in the company to allow them to consume more perquisites and invest in potential projects that will probably enhance their personal prestige but will not benefit shareholders. Firms with weaker corporate governance practices are subject to more managerial opportunism due to the reason that their managers have the chance to operate at their own discretions with almost no monitoring from shareholders. On the other hand, in companies with strong governance, managers are less likely to attempt to retain cash within the firm and rather pay out cash to shareholders. This hypothesis suggests that there is a positive relationship between dividend payouts and the quality of corporate governance. It is obvious that, the expected dividend policy is the outcome of governance regime and the stronger the shareholder rights, the more paid out as dividends (Jiraporn and Ning, 2006). La Porta et al. (2000) assert that companies will pay more dividends in countries with stronger legal protection to minority shareholders. In their study, they examined 4.000 firms from 33 different countries and indicated that companies operating in countries with stronger legal protection, pay higher dividends. Renneboog and Szilagyi (2006) state that the Dutch companies with strong shareholders demand higher dividend payouts. Michaely and Roberts (2006) emphasize that strong corporate governance encourages higher and more consistent dividend payouts.

On the other hand, John and Knyazeva (2006) in their study reported that total dividend payouts are significantly higher in countries with weak internal and external governance mechanisms. They interpret this finding as cash payment can be used as a device to provide the commitment of minority shareholders in countries with weak legal protection. Several other company-specific factors may also influence the dividend expectation behavior of outside shareholders. For example, within the context of the agency problem, if the internal corporate governance mechanisms of a firm and the minority shareholder rights in a country are strong, outside investors may be satisfied with lower dividend payments.

Payout policy is a good mechanism for avoding the manager-shareholder conflict. As John and Knyazeva (2006) state, dividends are effective mechanisms at mitigating the agency costs of free cash flow due to their pre-commitment nature and and higher costs of deviations from the dividend policy given the negative market reaction to dividend cuts. Companies with weak corporate governance are generally more exposed to managerial entrenchment and anticipate a more serious cash flow problem. Therefore, the necessity for dividends is greater for firms with weak shareholder rights than for firms with strong shareholder rights. Dividend payment imposes a tax burden on the payer firm and in addition to this, dividend-paying firm may also incur the additional cost of external financing to fund positive-NPV projects when internal cash flow is inadequate. Since dividends are costly, firms with better governance and firms that are less susceptible to managerial entrenchment should avoid the costs associated with dividends and should pay less dividends on average. On the other hand, firms that are more exposed to agency costs (those with weak corporate governance) should pay larger dividends. In other words, our second hypothesis, the substitution hypothesis, states that company dividend policies in the form of larger dividends are a substitute for weak corporate governance (Jiraporn et al., 2011).

According to the substitution hypothesis, a reputation for good treatment of investors is crucial for firms with weak corporate governance mechanisms. Therefore, dividend payout is important in the establishment of reputation for such firms. On the contrary, the need for reputation for companies with strong shareholder rights is weaker and so is 
the need for dividend payout. Consequently, dividends compensate for the weak shareholder rights and dividend payouts should be higher in companies with weaker corporate governance mechanisms, which indicates an inverse relation between the corporate governance and dividend payout (Jiraporn and Ning, 2006).

There are many studies on the relationship between ownership structure and dividend policy. Mehrani, Moradi and Eskandar (2011), in their paper, investigate the potential association between ownership structure and dividend policy in Tehran Stock Exchange between 2000 and 2007. The study concludes that there is a significant negative relationship between the institutional ownership and dividend payout ratio and a positive relationship between the concentrated institutional ownership and dividend payout ratio. However, the researchers could not find a significant association between the dividend policy and the managerial ownership. Ali Shah, Ullah and Hasnain (2011) conduct an empirical study to find out the potential impact of ownership structure on dividend payout policies of the Pakistani corporations listed at the Karachi Stock Exchange for the time period of 2002 and 2006. The findings of the study indicate that there is a significant positive association between ownership structure and dividend policy.

The study of Mirzaei (2012) aims to find out the relationship between the ownership structure and dividend policy. He conducts his study based on a sample of 88 companies listed at the Tehran Stock Exchange over the period of 2004 and 2009. The results of this study indicate that there is a significant negative relationship between institutional ownership and dividend policy. However, the researcher could not obtain a significant relationship between managerial ownership and dividend payment. Mirzaei (2012) also concludes that there is a positive and meaningful relationship between the variable of ownership concentration and dividend policy.

Warrad et al. (2012) examine the potential association between the ownership structure and the dividend policy for a sample of Jordanian industrial companies traded at the Amman Stock Exchange over the period of 2005 and 2007.The study concludes that that there is a not a significant relationship between the dividend policy measured by the Tobin's q and private ownership, government ownership, family ownership. However, results also indicate that there is a significant positive association between foreign ownership and dividend policy.

Ullah, Fida and Khan (2012) study the major factors that have an impact on the corporate dividend policy within the context of agency relation by utilizing several ownership structure variables such as institutional ownership, managerial ownership and foreign ownership. The data of the study is based on 70 randomly selected firms listed at the Karachi Stock Exchange 100 - index over the period of 2003 and 2010. The researchers found that managerial ownership has negative impact on the corporate dividend policy. On the other hand, institutional ownership and foreign ownership both have a positive impact on the dividend payments. The results of the study are important since they indicate how the corporate dividend policy can minimize the agency costs. The empirical analysis clearly reveals that dividends can be used as a disciplining mechanism to reduce the chance of the managers to expropriate the cash flow rights of the minority shareholders by decreasing the amount of FCF available to use of managers. This fact is also consistent with the finding of the study that managerial ownership has negative impact on the corporate dividend policy. This is mainly because, as a result of the increase in the managerial ownership, agency problems will decrease and dividend payments will drop significantly due to increase in managerial ownership.

Abdullah, Ahmad and Roslan (2012) analyze the impact of ownership structure on company dividend policy. They conclude that concentrated ownership has a significant positive influence on dividend policy. They find that managerial ownership is negatively associated with dividend policy in both models. However, results indicate that there is no relationships between foreign ownership and dividend policy.

Al-Gharaibeh, Zurigat and Al-Harasheh (2013) are other researchers, who try to investigate the impact of ownership structure on dividend policy by constructing a sample of 35 Jordanian companies listed at the Amman Stock Exchange over the period of 2005-2010. They prefer to use two empirical models, Full Adjustment Model and Partial Adjustment Model to analyze the potential relationship between ownership structures and dividend policy. The results of the study also suggest that managerial ownership has a negative influence on the dividend policy in the Partial Adjustment Model and therefore, as managerial ownership increases dividend payments fall. The researchers of the study assert that this is mainly due to the reason that managers have inclination to use FCF for their own personal benefits. On the other hand, Full Adjustment Model points out that there is a positive relationship between managerial ownership and dividend policy. According to Al-Gharaibeh et al. (2013), this relationship is a clear indication that Jordanian firms do not prefer to utilize dividends as a mechanism to reduce agency problems between company managers and shareholders. 


\section{Methodology}

In this study, we analyze the relationship between dividend policy and corporate governance. In recent years, corporate governance has become a more and more pronounced concept in the finance literature. Companies in the Borsa Istanbul (BIST) 100 Index also pay more attention to the concept of corporate governance to attract more foreign capital. They form their dividend payout policies in accordance with their corporate governance policies. To investigate the relationship between corporate governance and dividend policy we developed the following hypotheses :
$\mathrm{H} 1$ : Corporate governance has a signficant impact on dividend policy.
$\mathrm{H}_{2}$ : Ownership concentration has a signficant impact on dividend policy.
H3 : Managerial ownership has a signficant impact on dividend policy.
$\mathrm{H} 4$ : Foreign ownership has a signficant impact on dividend policy.

We developed our model in order to test whether the dividend payout policy is significantly associated with the level of corporate governance. The basic aim of our model is to reveal the strength and direction of association between the ownership concentration, foreign ownership, managerial ownership, return on equity and firm size in addition to corporate governance on dividend payout policy. We included two control variables to our study due to the reason that the ownership structure is not the only factor that may have a significant affect on dividend policy. The control variables that we employed in our study are firm size (SIZE) and return on equity (ROE). By including these two control variables into our model we aim to investigate the impacts of firm size and profitability on dividend payment. Standard OLS (Ordinary Least Squares) panel regression analysis has been performed by using Stata 10 for the analysis of our following model:

DIVPAYit $=\alpha+\beta 1 O W N C O N$ it $+\beta 2 M A N O W N$ it $+\beta 3 F O R T O T$ it $+\beta 4$ SCOREit $+\beta 5$ ROE it $+\beta 6$ SIZE it $+\varepsilon i t$ Table 1. Corporate Governance Scores of the Selected Companies

\begin{tabular}{lcccccccc}
\hline & 2007 & 2008 & 2009 & 2010 & 2011 & 2012 & 2013 & 2014 \\
\hline TOASO & 77,36 & 81,59 & 82,37 & 84,17 & 85,83 & 90,25 & 91,39 & 90,09 \\
TTRAK & 75,17 & 78,34 & 81,21 & 83,02 & 85,04 & 89,02 & 91,04 & 90,46 \\
TUPRAS & 79,12 & 82,02 & 83,41 & 85,58 & 86,20 & 91,00 & 93,43 & 93,10 \\
VESTL & 75,91 & 82,57 & 83,38 & 84,02 & 85,87 & 88,32 & 90,94 & 90,39 \\
OTKAR & & 79,40 & 81,20 & 83,18 & 84,68 & 86,80 & 91,03 & 91,99 \\
AEFES & & 80,96 & 82,71 & 84,00 & 85,46 & 89,39 & 93,30 & 94,20 \\
DENTA & & 70,75 & 78,18 & 80,29 & 80,60 & 86,90 & 89,73 & \\
CCOLA & & & 83,04 & 84,34 & 84,96 & 88,81 & 92,01 & 92,47 \\
ARCLK & & & 82,09 & 85,53 & 85,91 & 91,07 & 92,80 & 94,11 \\
TTKOM & & & 80,11 & 82,66 & 83,73 & 88,01 & 88,02 & 87,24 \\
TAVHL & & & 83,34 & 90,35 & 90,96 & 92,44 & 93,97 & 94,15 \\
PETKM & & & 77,13 & 81,90 & 85,20 & 87,20 & 89,10 & 90,10 \\
LOGO & & 80,53 & 81,71 & 82,61 & 85,97 & 89,12 & 90,29 \\
PRKAB & & 77,58 & 80,79 & 81,50 & 84,39 & 86,55 & 90,62 \\
TRCAS & & & & 75,20 & 81,20 & 84,00 & 87,51 & 90,90 \\
AYGAZ & & & & 84,61 & 84,95 & 89,57 & 92,71 & 92,93 \\
PRKME & & & & 86,45 & 86,66 & 88,24 & 89,80 & 89,45 \\
IHEVA & & & & 71,20 & 73,88 & 76,75 & 80,49 & 77,90 \\
DOAS & & & & & 77,05 & 86,30 & 90,05 & 92,50
\end{tabular}

Source : Website of Corporate Governance Association of Turkey (www.tkyd.org) 
Corporate governance scores of the selected non-financial companies, which are traded in the Borsa Istanbul (BIST) Corporate Governance Index (XKURY), are shown in Table 1. As shown in the table, 19 non-financial companies, which belong to different industries such as manufacturing, trade and service sectors, are included into our study. These scores are given by the rating institutions approved by the Capital Markets Board (CMB) to evaluate and rate the companies' compliance with the corporate governance principles of Turkey. The corporate governance score may vary between 70 to 100 . The study covers the time period between 2007 and 2014 . The abbreviations and the definitons of variables used in the study are indicated in Table 2.

Table 2. Abbreviations and Definitions of Variables Used in the Study

\begin{tabular}{|c|c|c|}
\hline Variable & & Abbreviation \\
\hline \multicolumn{3}{|l|}{ Dependent Variable } \\
\hline Dividend Payout Ratio & DIVPAY & The ratio of dividends paid by a company to its earnings \\
\hline \multicolumn{3}{|l|}{ Independent Variables } \\
\hline Ownership Concentration & OWNCON & $\begin{array}{l}\text { Total percentage of shares of the three biggest } \\
\text { shareholders }\end{array}$ \\
\hline Total Foreign Ownership & FORTOT & Total percentage of shares of the foreign shareholders \\
\hline Managerial Ownership & MANOWN & $\begin{array}{l}\text { A dummy variable of } 0 \text { if the Chairman of the Board } \\
\text { does not own any percentage of company shares and } 1 \text { if } \\
\text { the Chairman of the Board holds any percentage of } \\
\text { shares }\end{array}$ \\
\hline Corporate Governance Rating & SCORE & $\begin{array}{l}\text { Corporate governance score given by the rating } \\
\text { company, which should be at least } 70 \text { out of } 100 .\end{array}$ \\
\hline \multicolumn{3}{|l|}{ Control Variables } \\
\hline Return On Equity & ROE & The ratio of net profits after taxes to shareholder's equity \\
\hline Firm Size & SIZE & The natural logarithm of total assets \\
\hline
\end{tabular}

\section{Empirical Findings}

The empirical results of our research presented in Table 3 document a significant negative relationship between dividend payout ratio and ownership concentration (OWNCON) at $5 \%$ statistically significance level. Thus, the higher is the percentage of the ownership concentration in the firm the lower will be the dividend payment. This result can be interpreted as corporations with high insider ownership prefer to pay lower levels of dividends to their shareholders, which actually contradicts with the argument that firms aim to minimize costs related with agency conflict by distributing more dividends.

According to the empirical results of our study, we documented a significant negative relationship between managerial ownership (MANOWN) and dividend payout ratio at $1 \%$ significance level. Thus, the higher is the percentage of the managerial share ownership in the firm the lower will be the dividend payment. The relationship between the managerial ownership and dividend payout policy is important because it reduces the conflict of interest between managers and outside shareholders. It also helps to resolve information asymmetry between managers and external inverstors. There may be two main reasons for this negative association between managerial ownership and dividend payment. First, managers may wish to avoid incurring the legal regulation of double taxation. Secondly, managers may wish to retain profits for other purposes such as investing in profitable projects with future growth opportunities for the firm.

Total foreign ownership (FORTOT) has a significant positive association with the dividend payout ratio at 5\% significance level. Thereby, the higher is the foreign ownership in the firm the higher will be dividend payment. Our finding that foreign ownership has a positive impact on dividend payment is important in terms of pointing out how much foreign shareholding is influential on dividend policy that a company adopts. This result is also in line with the views of La Porta et al. (2000) that external shareholders try to receive as much cash dividends as they can from the company as a substitute for an effective legal protection mechanism.

The coefficient of corporate governance rating (SCORE) is statistically insignificant. Therefore, this result reveals that the level of corporate governance has no impact on dividend payout ratio. The fact that this analysis is based on only 19 companies from the BIST Corporate Governance Index (XKURY) has been effective on finding a 
statistically insignificant result. Although, Borsa Istanbul (BIST) 100 Index is composed of 100 companies, only 19 of them are included into our study since only these companies could obtain adequate scores to be listed in the BIST Corporate Governance Index (XKURY). For now, we do not have sufficient amount of information to reach meaningful results. However, as time passes and as the number of companies in this index increases, significant results may also be obtained to determine the relationship between corporate governance and dividend policy. To sum up, according to the results of this study, all the hypotheses are accepted except the first hypothesis that corporate governance has a signficant impact on dividend policy.

We obtained statistically meaningfull results related to our control variables. According to our findings, there is a significant negative assocation between davidend payment and return on equity (ROE). This result indicates that the higher is the profitability, the lower will be the dividend payment. This result is opposite to the general view that as the profitability increase companies choose to distribute more dividends. However, this negative relationship can be interpreted that if a company distributes dividends, then it reduces its retained earnings, which would also reduce its internally generated financing. For this reason, firms might prefer not to distribute cash dividends even though their profitability increases. Finally, our results indicate a statistically meaningful and positive association between firm size and dividend payment at the significance level of 5\%. This result reveals that larger firms can pay more dividends as compared to their smaller counterparts.

Table 3. The Estimation Results of Corporate Governance Model

(Dependent Variable : Dividend Payout Ratio)

\begin{tabular}{|c|c|c|c|}
\hline Independent Variable & & & t-statistics \\
\hline OWNCON & $-1.358^{* *}$ & $(-1.92)$ & \\
\hline MANOWN & $-0.558^{* * *}$ & $(-2.78)$ & \\
\hline FORTOT & $0.926^{* *}$ & $(2.68)$ & \\
\hline SCORE & 0.035 & $(1.89)$ & \\
\hline ROE & $-1.116^{* *}$ & $(-2.58)$ & \\
\hline SIZE & $0.568^{* *}$ & $(2,12)$ & \\
\hline Constant & -0.024 & $(-0.28)$ & \\
\hline Observations & 136 & & \\
\hline $\mathbf{F}$ & 4.525 & & \\
\hline $\mathbf{P}$ & 0.014 & & \\
\hline r2 & 0.185 & & \\
\hline $\begin{array}{l}\text { Breusch-Pagan / } \\
\text { Cook-Weisberg }\end{array}$ & $0.15(0.8224)$ & & \\
\hline Ramsey RESET Test & $0.86(0.5248)$ & & \\
\hline Woolridge Test & $1.648(0.3682)$ & & \\
\hline
\end{tabular}

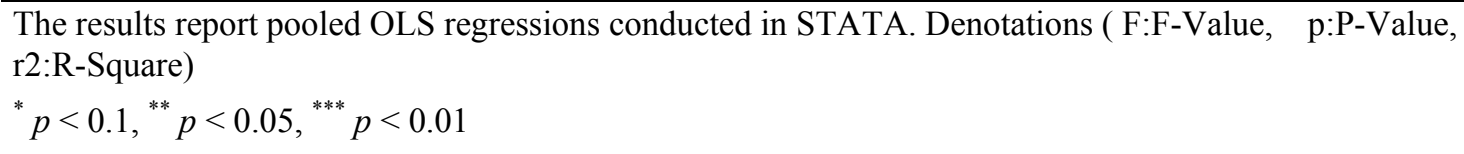

\section{Conclusion}

There may be special circumstances when shareholders may not prefer higher dividend payouts even if they are well protected by good governance mechanisms. One example to such a special circumstance would be when the firm has good investment opportunities available. La Porta et al (2000), indicate that there is a strong inverse relationship between growth opportunities and dividend payouts in countries with strong shareholder protection. When shareholders are convinced that their rights are well protected, they are more willing to allow company to retain cash rather than to distribute it with the hope of ganing more from good projects in the future. If investor protection is weaker and shareholders know that, they would probably be more insistent in their desire for dividends, and would try to extract whatever value they can regardless of the company's growth opportunities. Mitton (2004) finds the 
similar results complimentary to the studies of La Porta et al. (2000) that at firm-level, a strong inverse relationship between dividends and growth opportunities would be observed among companies with stronger corporate governance.

The empirical results of our research document a significant negative relationship between dividend policy and ownership concentration. This result contradicts with the existing literature that as ownership concentration increases, firms try to distribute more dividends to minimize agency conflicts in order to attract potential investors to invest into their companies. However, it is obvious that further research needs to be made to have an in-depth analysis of the relationship between dividend policy and ownership concentration.

On the other hand, we obtained significant negative association between managerial ownership and dividend policy. This meaningful negative relationship between managerial ownership and dividend payout is important and in line with the major literature. As Jensen (1986) points out, this result can be interpreted as managers choose to keep earnings instead of distributing them in the form of dividends. This is mainly due to managers' desire to use them to finance the growth of the company or to use them for their own personal benefits. It has been documented by various researchers that increasing dividend level reduces both agency costs and conflicts of interest between the managers and the minority shareholders. Because paying dividends to shareholders decreases management's control over company resources managers generally do not prefer to distribute cash dividends. However, as Ross (1977) argues both managerial ownership and dividends are two important mechanisms to reduce agency costs and the conflict of interests between the management and the outside shareholders. Due to the reason that both mechanisms are used for the same purpose, an inverse relationship is expected between the managerial ownership and dividend payout policy. Consequently, as managerial ownership increases firms choose to pay lower levels of dividends.

Our other empirical result that total foreign ownership has a positive impact on dividend payment is also important in terms of indicating how much foreign shareholding is affective on dividend policy that a company implements. With respect to the relationship between foreign ownership and dividend policy, various authors find mixed results. Researchers argue that foreign investors demand larger dividends due to the informational asymmetry between them and company managers. Agency theory states that it is difficult for foreign firms to monitor the financial activities of the invested companies. Therefore, foreign firms may demand managers to pay larger dividends in order to prevent opportunist managers from investing in unprofitable projects. As part of the global equity markets, corporate finance managers of the publicly traded companies should consider this fact when forming their dividend policy. Consequently, the higher the foreign shareholding in the company, the higher the dividend payment.

We also observed that the level of corporate governance has no impact on dividend payout since we obtained an insignificant result. The fact that this analysis is based on only 19 companies from the Borsa Istanbul (BIST) Corporate Governance Index (XKURY) has been effective on finding such a statistically insignificant result. In the long run, as the awarenesses and perceptions of investors and managers regarding the corporate governance rating scores improve, and as the number of companies in this index increases, more meaningful results can also be obtained to detemine the impact of corporate governance on dividend policy.

Finally, our empirical findings regarding our control variables indicate an inverse relationship between the dividend payment and return on equity (ROE). This result can be interpreted that even profitable firms might not want to increase their level of dividends when they have profitable investment opportunities. In the case of profitable investment projects, if a firm distributes its dividends, it reduces its retained earnings, which would affect its internally generated financing. Therefore, companies might not want to distribute dividends even though their level of profitability increases. Our final empirical finding reveals that firm size has a positive impact on dividend payment, which indicates that larger firms distribute more dividends as compared to smaller ones. This is mainly due to the reason that access to required funds is not a major problem for large companies. Jensen and Meckling (1976) argue that large companies pay larger dividends to reduce agency costs and minimize the information asymmetry problem between the management and insider owners and the outside shareholders.

To conclude, It is obvious that further research needs to be made to have an in-depth analysis of the relationship between corporate governance and dividend policy. As a suggestion for further research, various analyses can be conducted to compare the different corporate governance policies and practices of different emerging and developed countries. As emerging markets began to receive a higher proportion from the global equity investments, investors have also started to give more importance to the dividend policy choices of emerging market firms. In this respect, evaluation of the dividend policies and the corporate governance practices of emerging market countries will help to clarify whether companies in those countries pay more attention to the corporate governance practices and whether 
they follow more stable dividend policies to attract more foreign capital to their stock exchange markets to enhance their economic growths or not.

\section{References}

Abdullah, NMH, Ahmad, Z. \& Roslan, S. (2012). Capital Structure Effect on Firms Performance: Focusing on Consumers and Industrials Sectors on Malaysian Firms. International Review of Business Research Papers. 8 (5), 137-155.

Al-Gharaibeh, M., Al-Zurigat, Z. \& Al-Harasheh, K. (2013). The Effect of Ownership Structure on Dividends Policy in Jordanian Companies. Interdisciplinary Journal of Contemporary Research in Business. 4.9, 769-796.

Ali Shah, Z.S., Ullah, W. \& Hasnain, B. (2011). Impact of Ownership Structure on Dividend Policy of the Firm. 2010 International Conference on E-business, Management and Economics. Hong Kong : IACSIT Press.

Berle, A. A. \& Means, G. C. (1991). The Modern Corporation \& Private Property; With A New Introduction by Murray Weidenbaum \& Mark Jensen. New Brunswick, N.J., U.S.A.: Transaction Publishers. (Originally published in 1932).

Bhattacharya, S., (1979). Imperfect Information, Dividend Policy and the Bird-in-the-hand Fallacy. The Bell Journal of Economics. 10, 259-270. http://dx.doi.org/10.2307/3003330

Brush T.H, Bromiley, P. \& Hendrickx M. (2000). The Free Cash Fow Hypothesis for Sales Growth and Firm Performance. Strategic Management Journal. 21.4, 455-472. http://dx.doi.org/10.1002/(SICI)1097-0266(200004)21:4<455::AID-SMJ83>3.0.CO;2-P

Chae, J. Kim, S., \& Lee, E. (2009). How Corporate Governance Affects Payout Policy Under Agency Problems and External Financing Constraints. Journal of Banking and Finance. 33, 2093-2101. http://dx.doi.org/10.1016/j.jbankfin.2009.05.003

Chung, R., Firth, M. \& Kim. J.B. (2005). Earnings Management, Surplus Free Cash Flow, and External Monitoring. Journal of Business Research. 58, 766-776. http://dx.doi.org/10.1016/j.jbusres.2003.12.002

Coskun, M. \& Sayilir, O. (2012). Relationship Between Corporate Governance and Financial Performance of Turkish Companies. International Journal of Business and Social Science. 3(14), 59-64.

Easterbrook, F. (1984). Two Agency Cost Explanations of Dividends. American Economic Review. 74, 650-659.

Fama, F.E. \& Jensen C.M. (1983). Agency Problems and Residual Claims. Journal of Law \& Economics. Vol 26, July. http://dx.doi.org/10.1086/467038

Jensen, M. C. (1986). Agency Costs of Free Cash Flow, Corporate Finance, and Takeovers. American Economic Review. 76 (2) : 323-29.

Jensen, M. C. \& Meckling, W., H. (1976). Theory of the firm : Managerial Behavior, Agency Costs, and Ownership Structure. Journal of Financial Economics. 3, 305-360. http://dx.doi.org/10.1016/0304-405X(76)90026-X

Jiraporn, P., \& Ning, Y. (2006). Dividend Policy, Shareholder Rights, and Corporate Governance. Journal of Applied Finance. 16, 24-36. http://dx.doi.org/10.2139/ssrn.931290

Jiraporn, P., Kim, Y., \& Kim, J. (2011). Dividend Policy and Corporate Governance Quality: Evidence From ISS. The Financial Review. 46, 251-279. http://dx.doi.org/10.1111/j.1540-6288.2011.00299.x

Jo, H., \& Pan, C. (2009). Why are Firms with Entrenched Managers More Likely to Pay Dividends? Review of Accounting and Finance. 8, 87-116. http://dx.doi.org/10.1108/14757700910934256

John, K., \& Knyazeva, A. (2006). Payout Policy, Agency Conflicts, and Corporate Governance. Working Paper, New York University. http://dx.doi.org/10.2139/ssrn.841064

John, K., \& Williams, J., (1985). Dividends, Dilution, and Taxes : A Signalling Equilibrium. Journal of Finance. 40.4, 1053-1070. http://dx.doi.org/10.1111/j.1540-6261.1985.tb02363.x

Kaen, R.F. (2003). A Blueprint for Corporate Governance. New York : AMACOM.

Kowalevski, O., Stetsyuk, I. \& Tlavera, O. (2007). Corporate Governance and Dividend Policy in Poland. http://dx.doi.org/10.2139/ssrn.986111

La Porta, R. Lopez de Silanes, F., Shleifer, A. \& Vishny, R.W. (2000). Agency Problems, and Dividend Policy Around the World. Journal of Finance. 55.1, 1-33. http://dx.doi.org/10.1111/0022-1082.00199 
Lintner, J. (1956). Distributions of Incomes of Corporations Among Dividends, Retained Earnings, and Taxes. American Economic Review. 46.2, 97-113.

Mehrani, S., Mohammad M. \& Eskandar, H. (2011). Ownership Structure and Dividend Policy Evidence from Iran. African Journal of Business Management. 5.17, 7516-7525.

Michaely, R. \& Roberts, R.M. (2006). The Dividend Polices of Private Firms: Insights Into Smoothing, Agency Costs and Information Asymmetry. Available at https://business.rice.edu/uploadedFiles/Faculty_and_Research/Academic_Areas/Finance/Seminar_PDFs/Robert s_090806.pdf

Miller, M.H. \& Modiglianni, F. (1961). Dividend Policy, Growth and the Valuation of Shares. Journal of Business. 34.4, 411-433. http://dx.doi.org/10.1086/294442

Miller, M. H. \& Rock, K. (1985). Dividend Policy Under Asymmetric Information. Journal of Finance. 40, 1031-1052. http://dx.doi.org/10.1111/j.1540-6261.1985.tb02362.x

Mirzaei, H. (2012). A Survey On The Relationship Between Ownership Structure and Dividend Policy in Tehran Stock Exchange. International Conference on Management, Applied and Social Sciences, Dubai, 2012.

Mitton, T. (2004). Corporate Governance and Dividend Policy In Emerging Markets. Emerging Markets Review. 5, 409-426. http://dx.doi.org/10.1016/j.ememar.2004.05.003

Nielsen, A. (2006). Evolution of Corporate Governance, Externalities and Multiple Equilibria. mimeo. http://dx.doi.org/10.2139/ssrn.888832

Renneboog, G.P. \& Szilagyi, L. (2006). Corporate Restructuring and Bondholder Wealth. ILEC Discussion Paper No. 2006-007. Available at http://papers.ssrn.com/sol3/papers.cfm?abstract_id=899072.

Rozeff, M.S. (1982). Growth, Beta and Agency Costs as Determinants of Dividend Payout Ratios. Journal of Financial Research. 5, 249-259. http://dx.doi.org/10.1111/j.1475-6803.1982.tb00299.x

Sawicki, J. (2005). Changes In Corporate Governance and Dividend Policy Prompted By the Asian Financial Crisis. Available at http://www.fep.up.pt/conferencias/pfn2006/Conference\%20Papers/597.pdf

Shleifer, A. \& Vishny, R.W. (2000). A Survey of Corporate Governance. Journal of Finance. 52, 737-783. http://dx.doi.org/10.1111/j.1540-6261.1997.tb04820.x

Ullah, H., Fida, A. and Khan, S. (2012). The Impact of Ownership Structure on Dividend Policy Evidence from Emerging Markets KSE-100 Index Pakistan. International Journal of Business and Social Science. 3.9, 298-307.

Warrad, L., Suzan A., Khriasat, O. \& Al-Sheikh, I. (2012). The Effect of Ownership Structure on Dividend Payout Policy : Evidence from Jordanian Context. International Journal of Economics and Finance. 4(2), 187-195. http://dx.doi.org/10.5539/ijef.v4n2p187

Wu, M-C, Lin, H-C, Lin, I-C \& Lai, C-F. (2009). The Effects of Corporate Governance on Firm Performance.

www.tkyd.org 